\title{
The Determinants of Blockholder Presence: Evidence from Korea
}

\author{
Hung Sik KIM*, Kyung-Shick CHO**
}

Received: January 31, 2020 Revised: February 24, 2020 Accepted: March 6, 2020.

\begin{abstract}
The purpose of this study is to investigate the determinants of blockholder presence in the Korean stock market. This study examines previous theories and studies, points that previous studies did not examine, and proposes two hypotheses. To verify two hypotheses, fundamental data were collected from firms listed on Korea Exchange from 2005 to 2017. As explanatory variables, we use the factors and characteristics of the firms used in the previous studies. Logistic regression analysis was conducted to test the determinants of blockholder presence. We find that firm size is the most distinctive factor determining the presence of blockholder, and firm idiosyncratic risk is the most similar factor determining the existence of each blockholder. Tobin Q shows significant value in family and government, and R\&D intensity appears to be a negative related to the presence of blockholder in financial institutions. We also find that the determinant of blockholder presence differs from the mechanisms that govern each individual blockholder type when all blockholders grouped together. This suggests that there is blockholder heterogeneity within Korea listing firms. Our findings contribute to investors and policy makers who interested in the determinants of the presence of blockholder and blockhoder heterogeneity in Korea stock market.
\end{abstract}

Keywords : Blockholder Presence, Blockholder Heterogeneity, Firm Size, Idiosyncratic Risk, Tobin's Q

JEL Classification Code : G30, G32, G35

\section{Introduction}

This study is to investigate the determinants of each blockholder presence, and to analyze whether the determinants of each blockholder presence are the same or different. Blockholder is a shareholder with at least $5 \%$ ownership in the firm (Dlugosz, Fahlenbrach, Gompers, \& Metrick, 2006; Yim, 2020). In Korean corporate governance/ownership, blockholder has various types: Family (including affiliated person or companies), nonfamily, foreign, financial institutions, government and others (ESOPs) (Kim \& Cho, 2019).

${ }^{*}$ First Author. Professor, College of Management and Economics, Dongguk University Gyeongju Campus, Korea.

Email: kimhs@dongguk.ac.kr

${ }^{* *}$ Corresponding Author. Visiting Professor, College of Management and Economics, Dongguk University Gyeongju Campus, Korea. [Postal Address: 109-1411(Daewoo APT.),163, Dongbuk-ro, Bukgu, Daegu, 41519, Korea ]

E-mail: ksjoh@dongguk.ac.kr; and ksjoh@daum.net

(c) Copyright: The Author(s)

This is an Open Access article distributed under the terms of the Creative Commons Attribution Non-Commercial License (http://Creativecommons.org/licenses/by-nc/4.0/) which permits unrestricted noncommercial use, distribution, and reproduction in any medium, provided the original work is properly cited.
Why should this study be conducted? First, there are two major researches on ownership structure in advance studies. One is the internal ownership and the other is the determinants of the ownership concentration. In studies involving internal ownership, prior studies provide some evidence that there is a blockholder within a firm. This means that insiders with high ownership can be seen as one important blockholder. It is also means that the concentrated ownership explains the presence of blockholder. An important study on the determinants of ownership was established by Demsetz and Lehn (1985). They investigate cross-sectional determinants of ownership concentration in U.S. listed companies and find that concentrated ownership is associated with high levels of corporate risk. Recent studies focus on predicting changes in insider ownership structure over time and extend or remeasure many of these findings (Himmelberg, Hubbard, \& Palia, 1999; Denis \& Sarin, 1999; Fahlenbrach \& Stulz, 2009; Helwege, Pirinky, \& Stulz, 2007). Although there has been interest in blockholders in academia and practice, research on blockholders is rare in the Korean stock market.

Second, representative studies on blockholder presence are made by Dlugosz et al. (2006) and Holderness (2009). 
Dlugosz et al. (2006) analyze the panel analysis of U.S. listed companies in the late 1990s. They report that firms have two blockholders, and most shareholders are external blockolder. Holderness (2009) finds that about $96 \%$ of 375 firms have at least a blockholder and analyze the determinants of blockholder presence and size. In their study, U.S. listed companies demonstrate the existence of one and many blockolders within the firm. Recently, Hadlock and Schwartz-Ziv (2019) examine the determinants of blockholder presence in U.S. firms from 2001 to 2014. As a result of analysis, they report that the determinants of each individual blockholder are different, and interpret the result as blockholder heterogeneity. There have been many researches on the determinants of ownership in Korea (Lee \& Lee, 2003). However, it is also very rare to analyze the factors that determine the presence of each blokokholder in Korean stock market.

Third, although there is empirical literature investigating the causes and consequences of blockholder existence, the results are mixed. In particular, many foreign studies focus only on specific types of blockholders, while others focus on simple outcomes or corporate characteristics associated with blockholders. In terms of corporate governance/ownership structure, the blocholder pattern in Korea is different from the blockholder form in the foreign securities market such as the United States. For example, the first blockholder in the United States is often an institutional investor (Volkova, 2018). However, in TS2000, published by Korea Listed Companies Association, Korea's first shareholder is often known to be a family including affiliated or affiliated persons. In addition, unlike in the United States, foreign blockholder plays a very important role in the securities market in Korea. Therefore, it seems to be different in determining the existence of blockholder between Korean companies and foreign companies like U.S.

The purpose of this study is to answer the following two questions. First, what are the factors that determine each blockholder presence in the Korean stock market? Second, is there any heterogeneity of blockholders in the Korean stock market?

This study has three differences compared with the previous studies. First, this study is different in that we analyze the determinants of blockholder presence, while previous studies focus on the determinants of total shareholdings (Demsetz \& Lehn, 1985). Second, Hadlock and Schwartz-Ziv (2019) analyze the determinants of blockholder as individuals, corporations, strategic investors and financial institutions. However, this study divides blockholder into family, non-family, foreigners, financial institutions, and governments. In particular, we further analyze financial institutions separately as passive / active financial institutions. Third, we find that firm size is the most distinctive factor and firm idiosyncratic risk is the most similar factor in determining the presence of each blockholder, excepting firm characteristics. We also find that the factors that determine the presence of each blockholder are different in Korea stock market.

\section{Literature Review and Hypothesis}

\subsection{Blockholder Presence}

Dlugosz et al. (2006) and Holderness (2009) focus on the presence of blockholders. In a panel analysis of U.S. listed companies in the late 1990s, Dlugosz, et al. (2006) report that medium-sized firms have two blockholders and most blockholders are external large shareholders. Holdness (2009) report that U.S. firm has at least one blockholder. These studies clearly show that there is one and multiple blockholders in U.S. companies. Holderness (2009) also shows evidence for determining the presence and size of blockholder positions. However, these studies do not consider whether the types of blockholder are different within a firm.

\subsection{Determinants of Blockholder Presence}

Until now, studies on the determinants of blockholder presence have been rare. Many previous studies have focused on the determinants of inside ownership or ownership concentration. Insiders with high ownership are one important form of blockholder. Concentrated ownership generally represents the presence of important blockholder. Therefore, previous studies provide evidence for understanding blockholder presence.

Demsetz and Lehn (1985) have analyzes the crosssectional determinants of ownership concentration in U.S. listed companies. They use many variables as the determinants of ownership concentration. The variables are market value of common equity in thousands of dollars, stock market rate of return, accounting rate of return, standard error of estimate from market model in which firm's average monthly return, standard deviation of monthly stock market rates of return, standard deviation of annual accounting rates of return, capital expenditures, advertising, $R \& D$, value of total assets in millions of dollars. As a result of the analysis, they find that firm size and instability of profit rate are main determinants of ownership concentration. In particular, concentrated ownership finds relevance to higher levels of firm risk. This suggests that incentive or monitoring benefits of ownership are greater than risk-bearing costs in highly risky environments.

Subsequent authors review or extend the results of 
Demsetz and Lehn (1985). They focus on predicting changes in inside ownership over time rather than crosssectional determinants. For example, Himmelberg et al. (1999) investigate the determinants of managerial ownership through panel least squares using panel data. They use firm size, tangible asset, operating income/sales, idiosyncratic risk, R\&D, advertising, and capital expenditure as the determinants of managerial ownership. The analysis shows that the managerial ownership structure is explained by the main variables consistent with the predictions of the principal-agent model. It also reports that a large portion of the cross-section in managerial ownership structures is explained by unobserved firm heterogeneity.

Denis and Sarin (1999) investigate the determinants of ownership structure and board composition, and the change in ownership and board structure over time. To examine the determinants of ownership structure and board composition, they use firm size, risk, MTB, leverage, firm age, CEO tenure, founder dummy, and percentage of independent outsiders on board. They show that the determinants of ownership structure and board composition is firm size, MTB, leverage, and the ratio of independent outside directors are mixed. And the changes in ownership and board structure are strongly related to CEO turnover, previous stock price performance, and firm control threats. In addition, changes in ownership have occurred before the economic shock and asset restructuring followed.

Helwege et al. (2007) examine the evolution of insider ownership over time to understand better why and how U.S. corporations that become widely held do so. They find that a firm's performance and trading play an important role in insider ownership. Firms that undergo large decreases in insider ownership become widely held are firms with good performance, high valuations, and liquid markets. Fahlenbrach and Stulz (2009) show that managers are tend to decrease their ownership when their corporation are performing well and tend to increase their ownership when firm become financially constrained. When controlling for past share returns, they find that increases in managerial ownership increase Tobin's Q. There is no evidence that large decreases in ownership have a reverse effect on firm performance. However, factors suggested by agency theory have not explaining the evolution of insider ownership well. Hadlock and Schwartz-Ziv (2019) examine the determinants of the presence of blockholder in the sample of 129,632 companies from the U.S. listed companies from 2001 to 2014. They investigates that the determinants of blockholder existence between blockholder grouped together and by each individual type of blokokholder were different. They interpret this as the existence of blockholder heterogeneity and the existence of differences in the role of blockholder in corporate governance.

This study considers the determinants of blockholder existence using the factors used in the previous studies (Demsetz \& Lehn, 1985; Himmelberg et al., 1999; Denis \& Sarin, 1999; Helwege et al., 2007; Fahlenbrach \& Stulz, 2009, Hadlock \& Schwartz-Ziv, 2019). According to a study by Hadlock and Schwartz-Ziv (2019), this study uses firm size, idiosyncratic risk, Tobin's $Q$, and $R \& D$ as the main factors of blockholder presence, and also uses the sales growth rate, EBITDA, AD, tangible asset, leverage, and dividend dummy as firm characteristics.

\subsection{Blockholder Heterogeneity}

There are various blockholders in the firm. Many theories in the past assume that blockholders are relatively homogeneous groups. However, Dou, Hope, Thomas, and Zou (2018) show that individuals, financial institutions, and corporations are all represent substantial part of blockholder. Cronqvist and Fahlenbrach (2008) examine the effects of heterogeneity across blockholders. They find a fixed effect of blockholders in investment, finance, and executive compensation policies. They argue that this evidence suggests that blockholders vary in their beliefs, skills, and preferences. They also analyze that other blockholders have distinct investment and governance styles. For example, the approach to corporate investment and growth, the desire for financial leverage, and the attitude toward CEO pay.

There are reasons why these various types of blockholders are expected to play a different role in corporate governance. For example, a family blockholder can use ownership as an entrenchment device. Firm blockholder can use ownership positions to enhance or build product market relationships (Allen \& Phillips, 2000; Fee, Hadlock, \& Thomas, 2006). Blockholder of outsider individual or corporation and financial institution play a monitoring role within the firm. Edmans, Fang, and Zur (2013) argue that passive financial blockholder such as mutual funds play an important role in governance by influencing transaction decisions and management incentives. As we have seen, there are various types of blockholder. However, up to now, previous researches have not been conducted to investigate whether decision-making is different for each type of blockholder.

\subsection{Hypothesis}

In Korea stock market, we assume that the factors that determine the presence of each blockholders are different as in the United States, and the following hypothesis is established.

H1: The factors that determine the presence of each blockholder will be different. 
H2: Blockholder heterogeneity may exist in the Korea stock market.

\section{Research Methodology}

\subsection{Sampling and Data Collection}

This study selects sample firms based on the following criteria among companies listed on KOSPI and KOSDAQ of Korea Exchange from January 1, 2005 to December 31, 2017. (i) This study excludes companies that cannot obtain ownership, financial, and stock price data during the analysis period in TS-2000, which is provided by Korea Listed Companies Association and KIS VALUE Library, which is also provided by Korea Investors Service, Inc. (ii) The financial sector is excluded from the sample because it differs from the general manufacturing industry in terms of regulatory supervision, operating methods and financial statements. (iii) This study excludes companies whose settlement is not December 31. (iv) To control the effect of outliers on the analysis results, this study winsorize $1 \%$ of the top and bottom for each of the remaining variables except the blockholder ownership. The number of sampled companies was 646, of which 380 and 266 were KOSPI and KOSDFAQ, respectively.

\subsection{Measures}

In order to analyze whether a firm has a blockholder, we set logistic regression model as Eq. (1).

$$
\begin{aligned}
D_{-} B_{i t}= & \alpha_{0}+\beta_{1} L N T A_{i t}+\beta_{2} I R_{i t}+\beta_{3} Q_{i t}+\beta_{4} R D_{i t}+\beta_{5} S G_{i t} \\
& +\beta_{6} E B I T D A_{i t}+\beta_{7} A D_{i t}+\beta_{8} T A N_{i t}+\beta_{9} L E V_{i t} \\
& +\beta_{10} D \_D I V_{i t}+D_{-} Y R+e_{i t}
\end{aligned}
$$

Where, $D_{-} B=$ Blockholder presence dummy (1: Any, Family, Non-family, Foreign, Financial Institution, Government, All Non-Financial Institution, All Outsider Non-Financial Institution, 0: otherwise), $L N T A=\log$ (Total assets, Million won), $I R=$ Idiosyncratic risk, $Q=$ Tobin's $\mathrm{Q}$, $R D=\mathrm{R} \& \mathrm{D} /$ Total assets, $S G=$ Sales growth, EBITDA= EBITDA/Total assets, $A D=$ Advertising/Total assets, $T A N=$ Tangible assets/ Total assets, $L E V=$ Debt/Equity, $D_{-} D I V=$ Dividend dummy, $D_{-} Y R=$ Year dummy, $\mathrm{i}=$ firm $1 \ldots, \mathrm{N}, \mathrm{t}=$ 2005-2017 Yr.

The blockholder presence dummy used as a dependent variable in Eq. (1) assumes a value of 1 when a firm has any type of blockholder in a given year from 1 st blockholder to 5th blockholder. The major blockholder types are classified as any, family, non-family, financial Institution, foreign, government, all non-financial institution and all outsider non-financial institution. The classification standard refers to the largest shareholder in the company information and shareholder information in the COINS of TS-2000 provided by Korea company information (KOCOinfo). In Korea, family represents the total shareholding ratio of one largest shareholder, including a person with a special relationship that includes individuals and affiliate company. Non-family includes individuals and companies that hold more than 5\% stake, excluding persons with a special relationship.

Several variables used as explanatory variables in Eq. (1) refer to the determinants of insider ownership used in Himmelberg et al. (1999), Helwege et al. (2007), Mazumder (2017), Hadlock and Schwartz-Ziv (2019), and Kwan and Lau (2020). The variables introduced as explanatory variables are as follows: LNTA (total asset, million won), idiosyncratic risk, Tobin's $Q, R \& D$, sales growth, EBITDA, advertising, tangible assets, leverage, dividend dummy, and year dummy. This study focuses on the role of four major factors in predicting the presence of blockholder. Four key factors are firm size, firm idiosyncratic risk, Tobin's Q and R\&D intensity. Firm size and firm idiosyncratic risk are the most frequently used and most influential factors in determining ownership. And we use Tobin's Q and R\&D intensity to capture the presence of business growth opportunities. The tangible asset ratio is used as a substitute variable for incentives due to largest shareholder existence and benefit of largest shareholder monitoring activities. The remaining factors are used as characteristics of the firm.

The firm size is measured by taking the natural logarithm of the total assets (in million won) of each company. The firm idiosyncratic risk is estimated through a market model using the daily stock returns and daily market returns for each firm during the year t (Cao, Simin, \& Zhao, 2008; Dennis \& Strickland, 2004; Rossetto \& Stagliano, 2012). For this, regression analysis is carried out for each $i$ firm as in model (2).

$$
R_{i, T}=\beta_{1, i}+\beta_{2} R_{M K R i, T}+e_{i, T}
$$

Where, $R_{i, T}$ : The stock return of i-firm's T-days, $R_{M K R i, T}$ : The stock return of index's T-days

This study measures residual estimates through model (2). And the size of firm idiosyncratic risk is calculated by the method of Ang, Hodrick, Xing and Zhang (2006) as Eq. (3). This variable is winsorized at the 1st and 99th percentiles.

$$
I R_{i, t}=\sqrt{\frac{1}{n} \sum_{d=1}^{n}\left(\varepsilon_{i, t, d}\right)^{2}}
$$


Tobin's Q is measured as is the ratio of book value of total assets plus the market value of equity minus the book value of equity to the book value of total assets (Gompers, Ishii, \& Metrick, 2003). Tobin's Q is winsorized at the 1st and 99th percentiles.

$R \& D$ is measured as annual $R \& D$ spending divided by total year-end assets. Missing R\&D values assumed to be 0 . Sales growth (SG) is calculated by sales in the base year sales increase in the comparative year. EBITDA is calculated by the firm's annual earnings before interest, taxes, and depreciation divided by end of year total assets. $\mathrm{AD}$ means advertising spending. It calculated by the annual advertising spending divided by total year-end assets. Missing advertising values assumed to be 0 . TAN means asset tangibility. It measured as net property plant and equipment divided by end of year total book assets. LEV means book leverage. It calculated by the firm's total debt divided by end of year equity. D_DIV means dividend dummy. This variable assumes a value of 1 if the firm paid cash dividends during the most recent year and 0 otherwise. D_YR is year dummy. All independent variables are also winsorized at the 1st and 99th percentiles.

\section{Results}

\subsection{Descriptive Statistics}

Table 1 shows the types of blockholder, the number of blockholder, and descriptive statistics of independent variables. In Panel A of table 1, this study presents statistics for all years, the sample from 2005 to 2017 (columns 2 and 3 ), and the smallest and largest quartile firms (columns 4 and 5). Some interesting patterns arise from these comparisons.

Panel A shows the type of blockholder. First, the largest blockholder in Korea is the family blockholder $(0.939$, 93.9\%), which includes affiliated and affiliated persons. The survey results show that foreign block accounts for $0.145(14.5 \%)$ and financial institutions block account for $0.135(13.5 \%)$. Second, it can be seen that blockholder observations are slightly reduced from 1,057 to 1,046 over time. This is in contrast to the findings of Hadlock and Schwartz-Ziv (2019). They report an increase observation in blockholder over time. The trend of this study seems to be reflected in the decrease of foreign and government blockholder. Third, large firms have much more blockholder numbers than small and medium enterprises (SMEs). In the blockholder type, SMEs have more family and non-family blocks than large firms. However, large firms account for a high percentage of foreigners, financial institutions and governments rather than SMEs.

In Panel B, the proportion of at least one block in Korean companies is about $0.997(99.7 \%)$. Hadlock and Schwartz-Ziv (2019) report 91.6\%. This shows that Korean firms are slightly higher than U.S. firms. As the number of blockholders decreases over time, the fourth blockholder decreases $(27.7 \% \rightarrow 2.5 \%)$. However, the proportion of large companies is higher than that of SMEs from 1st blockholder to 5th blockholder.

Table 1: Sample Description

\begin{tabular}{|c|c|c|c|c|c|}
\hline & All years & 2005 & 2017 & Smallest Quartile Firms & Largest Quartile Firms \\
\hline \multicolumn{6}{|c|}{ Panel A: Blcokholder Type } \\
\hline Number of firm-years & 8,398 & 835 & 833 & 2,082 & 2,084 \\
\hline Observations of block-years & 14,058 & 1,057 & 1,046 & 2,862 & 4,360 \\
\hline Family blocks as fraction of total & 0.939 & 0.937 & 0.935 & 0.962 & 0.882 \\
\hline Non-Family blocks as fraction of total & 0.072 & 0.077 & 0.060 & 0.094 & 0.035 \\
\hline Foreign blocks as fraction of total & 0.145 & 0.155 & 0.125 & 0.069 & 0.235 \\
\hline Financial blocks as fraction of total & 0.135 & 0.116 & 0.115 & 0.054 & 0.210 \\
\hline Government blocks as fraction of total & 0.113 & 0.04 & 0.017 & 0.009 & 0.325 \\
\hline \multicolumn{6}{|c|}{ Panel B: Blockholder Number } \\
\hline Firm-years with at least 1 block & 0.997 & 0.998 & 0.995 & 0.996 & 0.997 \\
\hline Firm-years with at least 2 block & 0.273 & 0.214 & 0.216 & 0.206 & 0.364 \\
\hline Firm-years with at least 3 block & 0.106 & 0.079 & 0.070 & 0.054 & 0.183 \\
\hline Firm-years with at least 4 block & 0.037 & 0.277 & 0.025 & 0.015 & 0.072 \\
\hline Firm-years with at least 5 block & 0.020 & 0.097 & 0.013 & 0.003 & 0.036 \\
\hline \multicolumn{6}{|c|}{ Panel C: Independent Variables } \\
\hline
\end{tabular}




\begin{tabular}{|c|c|c|c|c|c|c|}
\hline \multicolumn{2}{|c|}{ Definition } & Obs. & Mean & Std. Dev. & Min & Max \\
\hline$L N T A$ & Ln of book assets & 8,398 & 12.307 & 1.444 & 9.858 & 17.031 \\
\hline$I R$ & Idiosyncratic risk & 8,398 & 0.028 & 0.011 & 0.010 & 0.065 \\
\hline$Q$ & Tobin's Q & 8,398 & 1.121 & 0.613 & 0.447 & 4.218 \\
\hline$R D$ & R\&D/Assets & 8,398 & 0.008 & 0.015 & 0.000 & 0.078 \\
\hline$S G$ & Sales growth & 8,398 & 0.063 & 0.233 & -0.553 & 1.108 \\
\hline$E B I T D A$ & EBITDA/Assets & 8,398 & 0.054 & 0.062 & -0.117 & 0.242 \\
\hline$A D$ & Advertising/Assets & 8,398 & 0.006 & 0.014 & 0.000 & 0.077 \\
\hline$T A N$ & Tangible asset/Assets & 8,398 & 0.302 & 0.182 & 0.002 & 0.759 \\
\hline$L V$ & Debt/Equity & 8,398 & 0.995 & 1.062 & 0.045 & 6.668 \\
\hline$D \_D I V$ & Dividend dummy & 8,398 & 0.633 & 0.482 & 0.000 & 1.000 \\
\hline
\end{tabular}

Table 2 shows Pearson correlation between independent variables. The correlation coefficient between the variables is 0.5 or less. The correlation coefficient is positive or negative. The Variance Inflation Factor (VIF) is presented to investigate the multicollinearity between variables. The values of VIF are within a statistical acceptable range. Therefore, multicollinearity problems are not a concern.

Table 2: Correlation Matrix

\begin{tabular}{|c|c|c|c|c|c|c|c|c|c|c|c|}
\hline & LNTA & IR & $\mathbf{Q}$ & RD & SG & $\begin{array}{c}\text { EBIT } \\
D A\end{array}$ & AD & TAN & $\mathbf{L V}$ & D_DIV & VIF \\
\hline LNTA & 1 & & & & & & & & & & 1.08 \\
\hline$I R$ & -0.309 & 1 & & & & & & & & & 1.06 \\
\hline$Q$ & -0.024 & 0.198 & 1 & & & & & & & & 1.11 \\
\hline$R D$ & -0.071 & 0.053 & 0.217 & 1 & & & & & & & 1.06 \\
\hline$S G$ & -0.004 & 0.039 & 0.101 & 0.031 & 1 & & & & & & 1.04 \\
\hline EBITDA & 0.132 & -0.144 & 0.174 & 0.046 & 0.262 & 1 & & & & & 1.18 \\
\hline$A D$ & 0.034 & -0.029 & 0.174 & 0.134 & 0.007 & 0.116 & 1 & & & & 1.05 \\
\hline TAN & 0.022 & -0.008 & -0.101 & -0.065 & -0.022 & 0.069 & -0.013 & 1 & & & 1.02 \\
\hline$L V$ & 0.173 & 0.114 & -0.005 & -0.088 & 0.012 & -0.156 & -0.116 & 0.128 & 1 & & 1.04 \\
\hline D_DIV & 0.200 & -0.233 & -0.058 & -0.042 & 0.120 & 0.345 & 0.112 & -0.011 & -0.287 & 1 & 1.19 \\
\hline
\end{tabular}

\subsection{Analysis Results}

In this section, this study investigates the factors that determine blockholder presence through logistic analysis. It is not easy to directly measure the cost or benefit of external monitoring, which is the factor that determines the existence of blockholder. This study refers to the factors used in the study of Himmelberg et al. (1999) and Helwege et al. (2007). They analyze the determinants of insider ownership structure. We also refer to the factors used in the study of Hadlock and Schwartz-Ziv (2019). The introduced variables are explained in detail in Eq. (1). This study focuses on the role of four important explanatory variables in predicting blockholder presence. Four explanatory variables are firm size, firm idiosyncratic risk, Tobin's Q, and R\&D intensity. Firm size and firm idiosyncratic risk play an important role in most of the previous studies on ownership structure. Tobin's Q and R\&D intensities reflect firm growth opportunities. In addition, tangible assets are used as a substitute variable to identify negative incentive results due to the presence of a blockholder, or to limit the benefit of the blockholder's monitoring activities. We assume the value of (1) when a firm has one blockolder in a given year, and $(0)$ if not.

Table 3 shows the results of analyzing the determinants of blockholder presence by type. The first column of Table 3 shows the coefficient estimates of the base model predicting blockholder presence of any type at a firm in a given year. The coefficient on two of the four main variables is negative and significant. This suggests that the risky firms and high Tobin's Q firms are less likely to have a blockholder. The magnitude of these variables is between -0.194 and -6.366 . This indicates that when the explanatory 
variable increases by one standard deviation, the probability of detecting a blockholder is significantly reduced. The overall sample frequency of blockholder presence in table 2 is $99.7 \%$

Table 3: Determinants of blockholder presence

\begin{tabular}{|c|c|c|c|c|c|c|c|c|}
\hline \multirow{3}{*}{ Variables } & \multicolumn{8}{|c|}{ Type of Blockholder Presence(1) } \\
\hline & Any & Family & $\begin{array}{l}\text { Non } \\
\text { family }\end{array}$ & Foreign & Financial & $\begin{array}{c}\text { Govern } \\
\text { ment }\end{array}$ & $\begin{array}{l}\text { All non } \\
\text { financial }\end{array}$ & $\begin{array}{c}\text { All } \\
\text { outside } \\
\text { nonfincl }\end{array}$ \\
\hline & (1) & (2) & (3) & (4) & (5) & (6) & (7) & (8) \\
\hline LNTA & $\begin{array}{l}-0.113 \\
(-0.14)\end{array}$ & $\begin{array}{c}-0.401 * * * \\
(-0.03)\end{array}$ & $\begin{array}{c}-0.325 * * * \\
(-0.04)\end{array}$ & $\begin{array}{c}0.280 * * * \\
(-0.02)\end{array}$ & $\begin{array}{c}0.202 * * * \\
(-0.02)\end{array}$ & $\begin{array}{c}0.842 * * * \\
(-0.03)\end{array}$ & $\begin{array}{c}-0.276^{* * *} \\
(-0.05)\end{array}$ & $\begin{array}{c}0.478 * * * \\
(-0.02)\end{array}$ \\
\hline$I R$ & $\begin{array}{c}-6.366^{* * *} \\
(-1.90)\end{array}$ & $\begin{array}{c}-4.444 * * * \\
(-1.27)\end{array}$ & $\begin{array}{c}-6.29 \\
(-4.01)\end{array}$ & $\begin{array}{c}-16.45 * * * \\
(-3.65)\end{array}$ & $\begin{array}{c}-6.714 * * \\
(-3.13)\end{array}$ & $\begin{array}{l}-2.563 \\
(-1.98)\end{array}$ & $\begin{array}{c}-7.196 * * * \\
(-1.43)\end{array}$ & $\begin{array}{c}-5.215^{* * *} \\
(-1.93)\end{array}$ \\
\hline$Q$ & $\begin{array}{l}-0.194 * \\
(-0.11)\end{array}$ & $\begin{array}{c}-0.254 * * * \\
(-0.06)\end{array}$ & $\begin{array}{l}-0.022 \\
(-0.06)\end{array}$ & $\begin{array}{c}0.033 \\
(-0.05)\end{array}$ & $\begin{array}{c}-0.03 \\
(-0.05)\end{array}$ & $\begin{array}{c}0.273 * * * \\
(-0.05)\end{array}$ & $\begin{array}{l}-0.122 \\
(-0.07)\end{array}$ & $\begin{array}{c}0.156^{* * *} \\
(-0.04)\end{array}$ \\
\hline$R D$ & $\begin{array}{l}-7.503 \\
(-8.43) \\
\end{array}$ & $\begin{array}{c}4.059 \\
(-3.22)\end{array}$ & $\begin{array}{l}-2.353 \\
(-2.66)\end{array}$ & $\begin{array}{l}-1.111 \\
(-2.11)\end{array}$ & $\begin{array}{c}-8.089 * * * \\
(-2.51)\end{array}$ & $\begin{array}{c}2.307 \\
(-2.69)\end{array}$ & $\begin{array}{c}18.970 * * \\
(-9.22)\end{array}$ & $\begin{array}{c}0.44 \\
(-1.67)\end{array}$ \\
\hline$S G$ & $\begin{array}{c}1.075 \\
(-0.89) \\
\end{array}$ & $\begin{array}{l}-0.088 \\
(-0.11) \\
\end{array}$ & $\begin{array}{c}0.117 \\
(-0.10) \\
\end{array}$ & $\begin{array}{c}0.063 \\
(-0.08) \\
\end{array}$ & $\begin{array}{l}0.151^{*} \\
(-0.08)\end{array}$ & $\begin{array}{c}-0.417 * * * \\
(-0.16)\end{array}$ & $\begin{array}{c}0.382 \\
(-0.37) \\
\end{array}$ & $\begin{array}{l}-0.029 \\
(-0.07) \\
\end{array}$ \\
\hline EBITDA & $\begin{array}{c}0.629 \\
(-1.90) \\
\end{array}$ & $\begin{array}{l}-1.512 * \\
(-0.81) \\
\end{array}$ & $\begin{array}{c}-1.025^{*} \\
(-0.53) \\
\end{array}$ & $\begin{array}{c}1.864 * * * \\
(-0.60)\end{array}$ & $\begin{array}{c}1.862 * * * \\
(-0.61)\end{array}$ & $\begin{array}{c}4.576 * * * \\
(-0.75)\end{array}$ & $\begin{array}{l}1.266^{*} \\
(-0.68) \\
\end{array}$ & $\begin{array}{c}1.531 * * * \\
(-0.49)\end{array}$ \\
\hline$A D$ & $\begin{array}{r}13.601 \\
(-24.03) \\
\end{array}$ & $\begin{array}{l}7.307 * \\
(-3.83) \\
\end{array}$ & $\begin{array}{c}9.899 * * * \\
(-2.31) \\
\end{array}$ & $\begin{array}{c}10.360 * * * \\
(-1.74)\end{array}$ & $\begin{array}{c}-4.730 * * \\
(-2.36) \\
\end{array}$ & $\begin{array}{c}-9.575^{* * *} \\
(-3.12)\end{array}$ & $\begin{array}{c}5.632 \\
(-8.85) \\
\end{array}$ & $\begin{array}{c}7.472 * * * \\
(-1.60)\end{array}$ \\
\hline TAN & $\begin{array}{c}-0.99 \\
(-1.02)\end{array}$ & $\begin{array}{c}-0.880 * * * \\
(-0.25)\end{array}$ & $\begin{array}{c}0.471 * * \\
(-0.24)\end{array}$ & $\begin{array}{c}-0.656 * * * \\
(-0.18)\end{array}$ & $\begin{array}{c}-0.600 * * * \\
(-0.18)\end{array}$ & $\begin{array}{c}0.171 \\
(-0.23)\end{array}$ & $\begin{array}{c}-0.71 \\
(-0.46)\end{array}$ & $\begin{array}{l}-0.062 \\
(-0.14)\end{array}$ \\
\hline$L V$ & $\begin{array}{l}0.043^{*} \\
(-0.02) \\
\end{array}$ & $\begin{array}{c}-0.021 * * \\
(-0.01)\end{array}$ & $\begin{array}{c}0.001 \\
(-0.02) \\
\end{array}$ & $\begin{array}{l}-0.015 \\
(-0.01) \\
\end{array}$ & $\begin{array}{c}0.001 \\
(-0.01) \\
\end{array}$ & $\begin{array}{l}-0.018 \\
(-0.01) \\
\end{array}$ & $\begin{array}{c}-0.029 * * * \\
(-0.01)\end{array}$ & $\begin{array}{l}-0.014 \\
(-0.01) \\
\end{array}$ \\
\hline$D \_D I V$ & $\begin{array}{c}1.939 * * * \\
(-0.58)\end{array}$ & $\begin{array}{c}0.618 * * * \\
(-0.11)\end{array}$ & $\begin{array}{c}0.222 * * \\
(-0.10)\end{array}$ & $\begin{array}{c}0.219 * * * \\
(-0.08)\end{array}$ & $\begin{array}{c}0.330 * * * \\
(-0.08)\end{array}$ & $\begin{array}{c}0.513 * * * \\
(-0.11)\end{array}$ & $\begin{array}{c}1.299 * * * \\
(-0.22)\end{array}$ & $\begin{array}{c}0.245^{* * *} \\
(-0.06)\end{array}$ \\
\hline$D_{-} Y R$ & & & & & uded & & & \\
\hline Constant & $\begin{array}{c}7.557 * * * \\
(-1.94)\end{array}$ & $\begin{array}{c}7.883 * * * \\
(-0.39)\end{array}$ & $\begin{array}{c}1.147 * * \\
(-0.53)\end{array}$ & $\begin{array}{c}-4.637 * * * \\
(-0.33)\end{array}$ & $\begin{array}{c}-4.208 * * * \\
(-0.33)\end{array}$ & $\begin{array}{c}-14.680 * * * \\
(-0.47)\end{array}$ & $\begin{array}{c}7.499 * * * \\
(-0.78)\end{array}$ & $\begin{array}{c}-7.085 * * * \\
(-0.27)\end{array}$ \\
\hline Observations & & & & & 398 & & & \\
\hline LR CHi2(22) & $42.05 * * *$ & $301.78 * * *$ & $104.47 * * *$ & $431.75 * * *$ & $239.02 * * *$ & $1757.17 * * *$ & $125.28 * * *$ & $1032.14 * * *$ \\
\hline Pseudo R2 & 0.128 & 0.078 & 0.024 & 0.062 & 0.036 & 0.297 & 0.1 & 0.102 \\
\hline
\end{tabular}

Note: This table reports the estimated marginal effect from a logistic model estimated at the firm-year level for a dependent variable that assumes a value of 1 if the firm has a blockholder of the indicated type as of the observation year. The independent variables are defined as: LNTA is Ln of book assets; IR is idiosyncratic risk; Q is Tobin's Q; RD is R\&D/Assets; SG is Sales growth; EBITDA is EBITDA/Assets; AD is Advertising/Assets; TAN is Tangible asset/Assets; LV is Debt/Equity; D_DIV is Dividend dummy; D_YR is Year dummy. Standard error is shown in parenthesis. ${ }^{* * *} \mathrm{p}<0.01,{ }^{* *} \mathrm{p}<0.05,{ }^{*} \mathrm{p}$ $<0.1$.

The analysis of the first column of Table 3 shows that the firm idiosyncratic risk has a significant negative impact on the likelihood of blockholder presence at $1 \%$ level. This result suggests that high risk bearing cost may restrict blockholder participation in the very risky companies. Tobin's Q has a negative impact on the probability of blockholder presence at the $10 \%$ level. This result can be interpreted in two ways. First, this result suggests that the monitoring activities of blockholder are less needed / valued at high performing companies. Second, these also imply that block ownership is harmful to the incentives needed to shape the blockholder in order to maximize the value of promising growth opportunities.

We next consider whether the factors that determine the presence of the blockholder discussed above predict the presence of each individual blockholder types. The estimation model is similar to the basic model discussed above. The difference, however, is that the firm uses a dependent variable that indicates whether it has a blockholder of the given type. The estimated effects of these logistic regression models for each of the five blockholders types are shown in columns 2 to 6 of Table 3 . 
The results of the analysis are summarized as follows.

First, as can be seen in the table, firm size (LNTA) coefficients are positive and negative, and are significant in five out of five blockholders types. The coefficients on size for family and government blockholder are relatively large. For example, the coefficient for family blcokholder is 0.401 and the coefficient for government blockholder are 0.842 . This means that the probability of observing a family (government) type blockholder decreases (increases) by 40.1

$\%(84.2 \%)$ when the firm size increases by one standard deviation from the mean. Firm size has a significant negative effect on the presence of family and non-family blockholder at $1 \%$ level. These results indicate that family and non-family blockholder investment decisions are negatively sensitive to firm size because of wealth constraints. It also shows that the ownership structure of family and non-family blockholder is generally less concentrated in large corporations. However, firm size has a significant positive effect on the presence of foreigners, financial institutions, and government blockholder at the $1 \%$ level. These results suggest that foreigners, financial institutions, and governments are likely to occupy more blockholder positions in large corporations. In other words, foreigners, financial institutions and governments can take a blockholder position of aversion against SMEs. This is due to institutional constraints.

Second, we look at firm idiosyncratic risk (IR). The coefficient of firm idiosyncratic risk is negative in all five categories, and family, foreign and financial institutions are statistically significant. This results shows that the risk aversion to firms in family, foreign, and financial institution is shown in previous results that there is a negative relation between blockholder presence of any type (model 1) and corporate risk. This result is in contradiction with the findings of Demsetz and Lehn (1985), which analyze the positive relation between ownership concentration and corporate risk. These are due to the fact that the monitoring activities or incentive benefits of concentrated ownership are greater than the cost of risk taking in a high risk environment.

Third, we analyze whether Tobin's Q (Q) has a significant effect on presence or absence of blockholder presence. As a result of the analysis, the coefficient value of Tobin Q shows significant value in family and government of five block categories. The family blockolder has a negative value and the government blockholder has a positive value. It is interpreted that Tobin's $\mathrm{Q}$ variable is related to the presence of family and government blockholder. This means that family blockholder are less likely to invest in high $\mathrm{Q}$ firms, while government blockholder are more likely to invest in high Q firms. However, there is no evidence that Tobin's Q affects the presence or absence of non-family, foreign and financial institution blockholder presence.

Fourth, this study examines the effect of R\&D (RD) variables on the presence or absence of blockholder. $R \& D$ intensity appears to be a negative related to the presence of blockholder in financial institutions. These results show that financial institution blockholder are less likely to invest in high R\&D companies. However, R\&D variables do not affect the existence of other blockholders.

Fifth, we consider a model that predicts the form of blockholder except financial institution blockholder. Estimates of the model are presented in column 8, Table 2. Non-financial block ownership is positively related to R\&D intensity and negatively related to firm size and Tobin's Q. We also consider a model that predicts the form of blockholder except insider such as family and financial institution blockholder. Estimates of the model are presented in column 9, Table 2. Outsider non-financial block ownership is negatively related to firm idiosyncratic risk and positively related to firm size and Tobin's Q.

The notable differences in the results of this study are as follows. First, firm size is the most interesting variable in predicting blockholder presence. While firm size negatively affects family and non-family blockholder presence, it positively affects the presence of foreign, financial institution and government blockholder presence. This means that family and non-family blockholder prefer small firms, while foreigners, financial institutions, and government blcokholder prefer large firms. Second, the other three major variables did not show statistically significant evidence for predicting non-family blockholder presence, excepting firm size. The Pseudo $\mathrm{R}^{2}(0.024)$ for this blockholder is the lowest among other blockholder types. This suggests that blockholder presence by type is heterogeneous within the firm. Third, this study finds a consistent negative relationship between each blockholder and firm specific risk, and a consistent positive relationship between each blockholder and dividend dummy. This suggests that each blockholder prefers a small risk and prefers a company that pays dividends.

\subsection{Robustness Check}

Table 4 shows the result of robustness check of the blockholder presence by type. We divide financial institutions into two types as distinguished by Ferreira and Matos (2008). One is passive financial institutions such as banks and insurance, and the other is an aggressive financial institution such as securities companies and asset management. Government agencies are also divides into two types. One is a pure government and the other is a national pension. We also analyze the presence of major institutional investors, including financial institutions and 
national pension service (NPS). The results show that there is positive relation between firm size and all 5 blockholder types (passive and aggressive financial, generic government, NPS, and institutional). These results are the same as the results in columns $4,5,6$, and 8 of Table 3 . Firm idiosyncratic risk has a positive effect on the presence of a passive financial institution, and negative effect on the presence of total institutional institution and an aggressive financial institution. This means that passive financial institution prefer firms with high corporate risk while an aggressive financial institution prefer firms with low corporate risk. Tobin's $\mathrm{Q}$ shows a positive effect on the presence of blockholder in three blockholders (passive financial, generic government, and NPS), excluding aggressive financial institutions and total institutional. These results indicate that passive financial institutions and government and NPS prefer to companies with high growth opportunities. R\&D intensity is related to the presence or absence of passive financial institutions and aggressive financial institutions.

In summary, this study shows that there is also blockholder heterogeneity in passive or aggressive financial institutions, generic government, and national pension service (NPS).

Table 4: Robustness Check

\begin{tabular}{|c|c|c|c|c|c|}
\hline \multirow{3}{*}{ Variables } & \multicolumn{5}{|c|}{ Type of Blockholder Presence(2) } \\
\hline & Passive Financial & $\begin{array}{c}\text { Aggressive } \\
\text { Financial } \\
\end{array}$ & $\begin{array}{c}\text { Generic } \\
\text { Government }\end{array}$ & $\begin{array}{c}\text { National Pension } \\
\text { Service(NPS) } \\
\end{array}$ & Institutional \\
\hline & (1) & $(2)$ & (3) & (4) & (5) \\
\hline LNTA & $\begin{array}{c}0.415 * * * \\
(-0.06)\end{array}$ & $\begin{array}{c}0.150 * * * \\
(-0.02)\end{array}$ & $\begin{array}{c}0.559 * * * \\
(-0.04)\end{array}$ & $\begin{array}{c}0.837 * * * \\
(-0.03)\end{array}$ & $\begin{array}{c}0.527 * * * \\
(-0.02)\end{array}$ \\
\hline$I R$ & $\begin{array}{c}6.200 * * * \\
(-1.52)\end{array}$ & $\begin{array}{c}-32.300 * * * \\
(-4.13)\end{array}$ & $\begin{array}{c}1.881 \\
(-2.27)\end{array}$ & $\begin{array}{l}-4.438 \\
(-2.81)\end{array}$ & $\begin{array}{c}-20.780 * * * \\
(-3.54)\end{array}$ \\
\hline$Q$ & $\begin{array}{c}0.163 * * \\
(-0.07)\end{array}$ & $\begin{array}{l}-0.017 \\
(-0.06)\end{array}$ & $\begin{array}{c}0.239 * * * \\
(-0.07)\end{array}$ & $\begin{array}{c}0.202 * * * \\
(-0.05)\end{array}$ & $\begin{array}{c}0.055 \\
(-0.04)\end{array}$ \\
\hline$R D$ & $\begin{array}{c}-28.710 * * \\
(-11.99)\end{array}$ & $\begin{array}{c}-6.029 * * \\
(-2.55)\end{array}$ & $\begin{array}{c}-8.66 \\
(-6.85)\end{array}$ & $\begin{array}{c}3.289 \\
(-2.84)\end{array}$ & $\begin{array}{l}-0.663 \\
(-2.10)\end{array}$ \\
\hline$S G$ & $\begin{array}{c}0.016 \\
(-0.27)\end{array}$ & $\begin{array}{c}0.206^{* *} \\
(-0.08)\end{array}$ & $\begin{array}{l}-0.445 \\
(-0.41)\end{array}$ & $\begin{array}{c}-0.380 * * \\
(-0.16)\end{array}$ & $\begin{array}{c}0.06 \\
(-0.08)\end{array}$ \\
\hline EBITDA & $\begin{array}{c}1.842 \\
(-1.73)\end{array}$ & $\begin{array}{c}1.621^{* *} \\
(-0.64)\end{array}$ & $\begin{array}{c}-1.728 * * \\
(-0.68)\end{array}$ & $\begin{array}{c}6.547 * * * \\
(-0.80)\end{array}$ & $\begin{array}{c}3.402 * * * \\
(-0.59)\end{array}$ \\
\hline$A D$ & $\begin{array}{c}-5.19 \\
(-8.95)\end{array}$ & $\begin{array}{c}-5.416^{* *} \\
(-2.45)\end{array}$ & $\begin{array}{l}-6.404 \\
(-7.43)\end{array}$ & $\begin{array}{c}-9.587 * * * \\
(-3.33)\end{array}$ & $\begin{array}{c}-5.552 * * * \\
(-2.11)\end{array}$ \\
\hline$T A N$ & $\begin{array}{c}0.258 \\
(-0.52)\end{array}$ & $\begin{array}{c}-0.767 * * * \\
(-0.19)\end{array}$ & $\begin{array}{c}2.282 * * * \\
(-0.44)\end{array}$ & $\begin{array}{c}-0.572 * * \\
(-0.25)\end{array}$ & $\begin{array}{c}-0.777 * * * \\
(-0.17)\end{array}$ \\
\hline$L V$ & $\begin{array}{c}0.036 * * * \\
(-0.01)\end{array}$ & $\begin{array}{c}-0.035^{* *} \\
(-0.02)\end{array}$ & $\begin{array}{l}0.023^{*} \\
(-0.01)\end{array}$ & $\begin{array}{c}-0.040 * * \\
(-0.02)\end{array}$ & $\begin{array}{c}-0.046^{* * *} \\
(-0.02)\end{array}$ \\
\hline$D \_D I V$ & $\begin{array}{c}-1.323^{* * *} \\
(-0.24)\end{array}$ & $\begin{array}{c}0.419 * * * \\
(-0.09)\end{array}$ & $\begin{array}{l}-0.354 * \\
(-0.20)\end{array}$ & $\begin{array}{c}0.748 * * * \\
(-0.12)\end{array}$ & $\begin{array}{c}0.537 * * * \\
(-0.08)\end{array}$ \\
\hline$D \_Y R$ & & & Included & & \\
\hline Constant & $\begin{array}{c}-8.957 * * * \\
(-0.79)\end{array}$ & $\begin{array}{c}-2.936^{* * *} \\
(-0.35)\end{array}$ & $\begin{array}{c}-11.800 * * * \\
(-0.68)\end{array}$ & $\begin{array}{c}-15.260 * * * \\
(-0.55)\end{array}$ & $\begin{array}{c}-8.003 * * * \\
(-0.34)\end{array}$ \\
\hline Observations & & & 8,398 & & \\
\hline LR CHi2(22) & $127.68^{* * *}$ & $328.13 * * *$ & $217.36^{* * *}$ & $1708.81 * * *$ & $1304.68 * * *$ \\
\hline Pseudo R2 & 0.118 & 0.052 & 0.147 & 0.32 & 0.159 \\
\hline
\end{tabular}

Note: This table also reports the estimated marginal effect from a logistic model estimated at the firm-year level for a dependent variable that assumes a value of 1 if the firm has a blockholder of the indicated type as of the observation year. Passive financial means bank, insurance, savings etc. Aggressive financial mean Securities, Investment Trust, Fund and Asset management etc. The independent variables are defined as: LNTA is Ln of book assets; IR is idiosyncratic risk; Q is Tobin's Q; RD is R\&D/Assets; SG is Sales growth; EBITDA is EBITDA/Assets; AD is Advertising/Assets; TAN is Tangible asset/Assets; LV is Debt/Equity; D_DIV is Dividend dummy; D_YR is Year dummy. Standard error is shown in parenthesis. ${ }^{* * *} \mathrm{p}<0.01,{ }^{* *} \mathrm{p}<0.05, * \mathrm{p}$ $<0.1$. 


\section{Discussion}

The purpose of this study is to answer the following two questions. First, what determines the presence of blockholder in the Korean stock market? Second, is there blockholder heterogeneity in the Korean stock market? This topic is important. This is because the role of blockholder in corporate governance is an issue that has received great attention in the financial field.

In the firm size, this study shows no significant evidence as a determinant of blockholder existence. These results are different from those of Hadlock and SchwartzZiv (2019). They show results consistent with many previous studies that ownership structures are generally less concentrated in large firms. However, we confirm that firm idiosyncratic risk has a significant negative impact on the likelihood of blockholder presence. This result suggests that high risk bearing cost may restrict blockholder participation in the very risky companies in Korea stock market. Tobin's $\mathrm{Q}$ has a negative impact on the probability of blockholder presence. This result also can be interpreted in two ways. First, this result suggests that the monitoring activities of blockholder are less needed / valued at high performing companies. Second, these also imply that block ownership is harmful to the incentives needed to shape the blockholder in order to maximize the value of promising growth opportunities in Korea stock market. The results are the same as those of Hadlock and Schwartz-Ziv (2019), which analyze US listed companies. We also confirm that the determinants of blockholder existence differed from the mechanisms that govern each blockholder type when all blockholders grouped together. This implies that blockholder heterogeneity exists in the Korean stock market.

\section{Conclusion}

This study investigated the determinants of the blockholder presence and whether blockholder heterogeneity exists in Korea stock market. We found that foreign, financial, government, and all outside nonfinancial blockholders prefer large firms, while family, non-family, and all-non financial prefer small firms. We also found that all each blockholder prefers a small firm specific risk. Tobin's Q showed a negative related to family blockholder, and a positive related to the government and all outside nonfinancial. RD showed a negative related to financial blockholders, and a positive related to all non-financials. However, the rest of the blockholders showed no significant evidence with Tobin's Q and RD. The most peculiar in the firm characteristic factor is that the dividend dummy has a significant positive relationship with all each blockholders. We also found that the determinants of blockholder existence differed from the mechanisms that govern each blockholder type when all blockholders grouped together. Non-family blockholder among the blockholder type showed the lowest and explanatory power. This suggests that there is blockholder heterogeneity in Korea stock market.

Our findings contribute to our understanding regarding determinants of blockholder presence and blockhoder heterogeneity in Korea stock market. In addition, even though Korean governance / ownership structure is different from that of U.S. firms, we believe that there is an important policy application for academic and corporate policy makers regarding the presence of blockholder heterogeneity. There are three implications for our research. First, in terms of ownership structure, U.S. blockholder composition is different from that of Korea. This study contributes to filling the gap in the existing literature. Second, in the factors that determine the presence of each blockholder, we found that there is a difference from previous studies. The results of this study can be applied to countries with a high proportion of family blockholders. Finally, this research provides helpful ideas and empirical evidence on the determinants of the presence of blockholder in Korea is very useful to investor, regulators, and other stakeholders.

\section{References}

Allen, J. W., \& Phillips, G. M. (2000). Corporate equity ownership, strategic alliances, and product market relationships. The Journal of Finance, 55(6), 2791-2815.

Ang, A., Hodrick, R. J., Xing, Y., \& Zhang, X. (2006). The crosssection of volatility and expected returns. The Journal of Finance, 61(1), 259-299.

Cao, C., Simin, T., \& Zhao, J. (2008). Can growth options explain the trend in idiosyncratic risk? The Review of Financial Studies, 21(6), 2599-2633.

Cronqvist, H., \& Fahlenbrach, R. (2008). Large shareholders and corporate policies. The Review of Financial Studies, 22(10), 3941-3976.

Demsetz, H., \& Lehn, K. (1985). The structure of corporate ownership: Causes and consequences. Journal of Political Economy, 93(6), 1155-1177.

Denis, D. J., \& Sarin, A. (1999). Ownership and board structures in publicly traded corporations. Journal of Financial Economics, 52(2), 187-223.

Dennis, P., \& Strickland, D. (2004). The determinants of idiosyncratic volatility (Working Paper). University of Virginia, Charlottesville, VA.

Dlugosz, J., Fahlenbrach, R., Gompers, P., \& Metrick, A. (2006). Large blocks of stock: Prevalence, size, and measurement. Journal of Corporate Finance, 12(3), 594-618.

Dou, Y., Hope, O. K., Thomas, W. B., \& Zou, Y. (2018). blockholder exit threats and financial reporting quality. Contemporary Accounting Research, 35(2), 1004-1028. 
Edmans, A., Fang, V. W., \& Zur, E. (2013). The effect of liquidity on governance. The Review of Financial Studies, 26(6), 14431482 .

Fahlenbrach, R., \& Stulz, R. M. (2009). Managerial ownership dynamics and firm value. Journal of Financial Economics, 92(3), 342-361.

Fee, C. E., Hadlock, C. J., \& Thomas, S. (2006). Corporate equity ownership and the governance of product market relationships. The Journal of Finance, 61(3), 1217-1251.

Ferreira, M., \& Matos, P. (2008). The colors of investors' money: The role of institutional investors around the world. Journal of Financial Economics, 88(3), 499-533.

Gompers, P., Ishii, J., \& Metrick, A. (2003). Corporate governance and equity prices. Quarterly Journal of Economics, 118(1), 107-155.

Hadlock, C. J., \& Schwartz-Ziv, M. (2019). Blockholder heterogeneity, multiple blocks, and the dance between blockholders. The Review of Financial Studies, 32(11), 41964227. https://doi.org/10.1093/rfs/hhz022.

Helwege, J., Pirinsky, C., \& Stulz, R. M. (2007). Why do firms become widely held? An analysis of the dynamics of corporate ownership. The Journal of Finance, 62(3), 995-1028.

Himmelberg, C. P., Hubbard, R. G., \& Palia, D. (1999). Understanding the determinants of managerial ownership and the link between ownership and performance. Journal of Financial Economics, 53(3), 353-384.

Holderness, C. G. (2009). The myth of diffuse ownership in the United States. The Review of Financial Studies, 22(4), 13771408 .
Kim. H. S., \& Cho, K. S. (2019). Are the factors determining the size of block ownership different? Evidence from Korea. International Journal of Economics and Management, 13(2), 343-356.

Kwan, J. H., \& Lau, W. Y. (2020). Do firm characteristics and industry matter in determining corporate cash holdings? Evidence from hospitality firms. Journal of Asian Finance, Economics and Business, 7(2), 9-20. https://doi.org/10.13106/jafeb.2020.vol7.no2.9

Lee, H. Y., \& Lee, J. C. (2003). An empirical study on the determinants of ownership structure of listed companies in Korea: Evidence from panel data. The Korean Journal of Financial Management, 20(2), 41-72.

Mazumder, M. M. M. (2017). Top-executive compensation: The role of corporate ownership structure in Japan. Journal of Asian Finance, Economics and Business, 4(3), 35-43. http://dx.doi.org/10.13106/jafeb.2017.vol4.no3.35

Rossetto S., \& Stagliano, R. (2012). The existence of blockholders and corporate governance, empirical evidence from U.S. Paper presented at the 29th International Conference of the French Finance Association (AFFI), June 7, 2012.

Volkova, E. (2018). Blockholders diversity: Effect of polyphony on the power of monitoring ( $\mathrm{PhD}$ Dissertation). University of Melbourne, Department of Finance. Melbourne, Australia..

Yim, S. G. (2020). Individual blockholder's influence on accounting quality: Evidence from Korea. Journal of Asian Finance, Economics and Business, 7(1), 59-69. https://doi.org/10.13106/jafeb.2020.vol7.no1.59 